\title{
MIR205 wt Allele
}

National Cancer Institute

\section{Source}

National Cancer Institute. MIR205 wt Allele. NCI Thesaurus. Code C82161.

Human MIR205 wild-type allele is located in the vicinity of $1 \mathrm{q} 32.2$ and is 109 bases in length. This allele, which encodes the MIR205 pre-miRNA, plays a role in the regulation of gene expression. Alteration in the expression of this gene is associated with the development of breast cancer and squamous carcinoma. 